\title{
The rhetoric and practice of the 'ownership' of security sector reform processes in fragile countries: the case of Kosovo
}

\section{Selver B. Sahin}

To cite this article: Selver B. Sahin (2017) The rhetoric and practice of the 'ownership' of security sector reform processes in fragile countries: the case of Kosovo, International Peacekeeping, 24:3, 461-488, DOI: $10.1080 / 13533312.2016 .1196107$

To link to this article: https://doi.org/10.1080/13533312.2016.1196107

\section{Published online: 20 Jun 2016.}

Submit your article to this journal $\sqsubset$

Џll Article views: 401

Q View related articles $\square$

View Crossmark data ¿

Citing articles: 4 View citing articles $\sqsubset$ 


\title{
The rhetoric and practice of the 'ownership' of security sector reform processes in fragile countries: the case of Kosovo
}

Selver B. Sahin

\begin{abstract}
Successful outcomes in security sector reform (SSR) implementation are often conditioned on two key inter-related operational principles: international agencies' understanding of the 'local context' where they intervene and their encouragement of the country 'ownership' of the institutional reforms they advocate. Outcomes, however, are determined by power, and different patterns of outcomes are likely to emerge from different types and degrees of power exercised by a multiplicity of actors operating in a dynamic political and social context. Drawing upon these inter-connections between outcomes and power, this article examines Kosovo's security sector development experience since 1999. It argues that depending on types of, and changes in, power-based interplays between international and domestic forces, different patterns of 'ownership' have emerged in the context of SSR implementation in Kosovo.
\end{abstract}

Responding to domestic governance deficits in the developing world has been at the centre of the international peacebuilding agenda since it was first formulated in the Secretary-General's 'Agenda for Peace'. ${ }^{1}$ In this landmark UN document released in 1992 and many other related international policy reports produced since then, ${ }^{2}$ peace is conceptualized by reference to conflict and insecurity that are associated with the inability of the state to enforce law and order over its territory and meet the basic security needs of its citizens in an effective and democratic way. Poor or bad governance, from this perspective, causes violent conflict, and the UN and other international agencies should provide 'support for the transformation of deficient national structures and capabilities, and for the strengthening of new democratic institutions' in order to 'solidify' peace. ${ }^{3}$ Security sector reform (SSR) represents this institutions-focused approach to peacebuilding: that is, enabling conditions of durable peace requires the creation of effective state security institutions

CONTACT Selver B. Sahin selver.sahin@bilkent.edu.tr

'UN, 'An Agenda for Peace'.

${ }^{2}$ Among others, see, for example, UN, A More Secure World; UN, 'Securing Peace and Development'; OECD/ DAC, Supporting Statebuilding; DFID, Eliminating World Poverty; World Bank, 2011 World Development Report; UNDP, Peace for Governance.

${ }^{3}$ UN, 'An Agenda for Peace', para. 59.

๑ 2016 Informa UK Limited, trading as Taylor \& Francis Group 
operating in accordance with human rights, transparency, accountability, social inclusion and the rule of law.

The first SSR programme was put into practice in Sierra Leone in 1997 as part of the country's United Kingdom-assisted post-conflict reconstruction process, and has since then become integral to peacebuilding initiatives undertaken from Afghanistan to the Solomon Islands. It is, at the same time, widely recognized that SSR is essentially a very sensitive undertaking. The involvement of foreign actors in security and defence-related issues that are considered to be 'the traditional cornerstones of state sovereignty' ${ }^{4}$ has the potential to create tensions between international and national actors. In addition to this, 'conflict-affected' and 'fragile' states where security institutions are fractured along ethnic or tribal lines and form part of the security problem offer the least favourable conditions for institutional restructuring. ${ }^{5}$ For instance, in Timor-Leste, where the UN was mandated to assist with the reform of the national security sector following the 2006 security breakdown, the national government insisted on 'solving their problems' in a 'Timorese way' ${ }^{6}$ and showed little interest in implementing UN recommendations, including a vigorous vetting process for the military, prosecution of police officers linked to the violence in 2006 and clearly delineating the roles and responsibilities of the police and the military. ${ }^{7}$ Undoubtedly, SSR programmes go beyond technical endeavours to include highly sensitive political tasks that require redistribution of power along liberal democratic principles. For instance, civilian control of armed forces, which is a key element of democratic security sector development, entails rearrangement of existing power relations. The reform process may result in existing civilian authorities consolidating their position and the power of interest groups they represent or align with. It may also be possible for reforms to generate resistance from disgruntled groups whose interests are threatened, resulting in spikes in violence or forced change of power. As evidenced by repeated peacebuilding interventions focusing on state institutions in Timor-Leste, Somalia, Haiti, Cote D'Ivoire, Liberia and the Democratic Republic of Congo, the results in building democratically functioning, competent security institutions have been less than successful.

In an attempt to overcome these shortcomings, two inter-related operational principles were developed and prioritized in donor discourses for more successful SSR outcomes: that is, international actors' understanding of the 'local context' where they are intervening and their encouragement of the country 'ownership' of the institutional reforms advocated. ${ }^{8}$ From

\footnotetext{
${ }^{4}$ OECD/DAC, OECD-DAC Handbook, 29; DFID, Understanding and Supporting, 13.

${ }^{5}$ OECD/DAC, OECD-DAC Handbook, 29.

${ }^{6}$ Pinto, 'UNMIT Mission'.

7International Crisis Group (ICG), 'Timor-Leste'; Sahin and Feaver, 'Politics of Security Sector Reform'.

${ }^{8}$ OECD/DAC, OECD-DAC Handbook; UN, 'Securing Peace and Development'; OECD/DAC, Security System Reform: What Have We Learned?; UN, 'Securing Peace and Development'; UN, 'Securing States and
} 
this perspective, intervening actors should pay more attention to the needs, concerns and practices of local populations through participatory approaches. The institutional reforms and policy frameworks devised in accordance with local needs and demands are thought to be 'owned' at the national level and more successful and sustainable results would thus be achieved.

Outcomes, on the other hand, are determined by power, and different patterns of outcomes are likely to emerge from different types and degrees of power exercised by a multiplicity of actors operating in a dynamic political and social context. Power, in other words, is not an object that one actor possesses and another does not. It is rather an attribute of a 'relational' experience that is bound to be both asymmetric and interdependent. ${ }^{9}$ This means that actors perform a 'function' for each other and are therefore dependent on each other, and if a particular actor is 'more dependent on' another, the latter has power over the former. ${ }^{10}$ Looked at this way, power can be examined in terms of actors' attempts to exercise mutual influence on outcomes as the forms of constraints they use against each other are rooted in the 'particular nature of their relatedness and interdependence as players'. ${ }^{11}$ Applying this approach to power as a relational experience to the analysis of the domestic landscape within which SSR measures are negotiated and implemented may help us better understand and explain (rather than describe) as to how 'ownership' in effect develops through domestic and international agencies' mutual dependencies and relative ability to use different modes of power (such as legitimization and appropriation) to influence outcomes.

Taking these inter-connections between outcomes and power as a point of departure, this study aims to contribute to the peacebuilding literature on SSR 'ownership' through offering an analysis of types of 'ownership' that are determined by power-based interplays occurring in a dynamic 'local context'. It does so by using a conceptual framework that helps identify how actors' mutual dependencies shape and constrain their ability to influence policy decisions and actions, as manifested in Kosovo's SSR experience since the NATO (North Atlantic Treaty Organization) intervention in 1999. It is argued that depending on forms of, and changes in, power relationships between international and domestic forces, different patterns of 'ownership' have emerged in the context of SSR implementation in Kosovo.

The article is organized into three main sections. It begins with a conceptual discussion of 'local context' and 'ownership'. The second part elaborates on an analytical framework that is employed to the study of Kosovo's SSR experience. This analytical framework previously referred to by $\mathrm{Bu}$ Wilson

Societies'; Scheye and Peake, 'Unknotting Local Ownership'; Nathan, No Ownership, No Commitment; Donais, 'Understanding Local Ownership'; Mobekk, 'Security Sector Reform'.

${ }^{9}$ Elias, What Is Sociology?

${ }^{10}$ lbid., 93.

${ }^{11}$ Ibid., 96 . 
in her work on the 'local ownership' of the UN-led police reform process in Timor-Leste ${ }^{12}$ constitutes a useful tool for the examination of the SSR activities in Kosovo. The final section is focused on the political and operational dimensions of these two principles in relation to Kosovo's security sector development experience.

\section{Local context and ownership: a conceptual analysis}

The idea that context-specific, 'bottom-up' strategies should be pursued to operationalize 'ownership' is now mainstreamed into the peacebuilding agenda for more successful results. The 'rediscovery of the local' in the face of failures of 'top-down' peacebuilding measures ${ }^{13}$ has received specific emphasis in relation to SSR implementation, which aims to foster democratic governance and deliver more effective justice and security through institutional measures. ${ }^{14}$ Yet, the principles of treating the 'local context' as the main reference point and achieving country 'ownership' prioritized at the policy level for 'good international engagement in fragile states and situations ${ }^{15}$ are not only characterized by a series of ambiguities and contradictions but run the risk of appropriation by policy-makers to justify and reinforce their regulatory practices. ${ }^{16}$

To start with the conceptual ambiguities and operational contradictions surrounding these two externally devised principles to bolster local compliance, it remains unclear what specifically forms the 'local context'. A brief overview of OECD/DAC guidelines suggests that donors should: (1) 'take context as the starting point $; ;{ }^{3}$ (2) possess the knowledge about the history and politics of a country in which they are intervening; and (3) consider how the existing patterns of state-society relations, sources of legitimacy and the balance of power between different social groups will be affected by their interventions. ${ }^{18}$ In facilitation of the production of context-specific, detailed analysis of the local capacity, political will and understandings of legitimacy, intervening actors are also advised (1) to use methodological approaches that go 'beyond quantitative indicators of conflict, governance or institutional strength', and (2) distinguish between different situations and degrees of political transition, deteriorating governance environments and crisis situations to be able to better respond to specific country and regional needs. ${ }^{19}$

\footnotetext{
${ }^{12}$ Wilson, Smoke and Mirrors.

${ }^{13}$ Mac Ginty, 'Where Is the Local?'

${ }^{14}$ Scheye, 'Unknotting Local Ownership Redux'.

${ }^{15}$ OECD/DAC, 'Principles for Good International Engagement'.

${ }^{16}$ Mac Ginty, 'Where Is the Local?'

${ }^{17} \mathrm{OECD} / \mathrm{DAC}$, 'Principles for Good International Engagement'. https://www.eda.admin.ch/content/dam/ countries/countries-content/nepal/en/38368714.pdf (accessed June 9, 2016).

${ }^{18}$ OECD/DAC, Do No Harm.

${ }^{19}$ Ibid., 147.
} 
However, the implementation of the principle of 'taking context as the starting point' has been mixed, as documented in donor reports. A 2005 OECD/DAC global survey of non-OECD countries' views on the SSR policy agenda, for instance, suggests that ' $[\mathrm{d}]$ onors often lack adequate understanding of the country in which they are engaging, in particular relating to how countries perceive and define security threats, how security institutions function, and the concerns of the reforming government. ${ }^{20}$ A more recent OECD/DAC study on the implementation of the principles for good international engagement in fragile states found that 'the analytical effort required to understand the country context has not always been shared $[\ldots]$ or sustained $[\ldots]$ [and] actual programming has not always been adequately rooted in an understanding of the country context ${ }^{21}{ }^{21}$ In most cases, the exercise of reviews, consultations and evaluations, in other words, turned into one of 'box-ticking' to formally comply with documentary requirements prioritized in donor guidelines. It is also a general problem that different actors produce different interpretations of domestic and regional dynamics. These 'multiple and fragmented analyses' of the realities on the ground make it extremely difficult to devise coherent and sequential policy instruments around commonly agreed development priorities, undermining the overall benefits of capacity-building programmes. ${ }^{22}$

When it comes to the related principle of 'ownership', it also suffers from conceptual ambiguities, loose definitions and contradictory practices that further undermine its already problematic substance and value. In its literal meaning, the term 'ownership' refers to the legal right of possession and is taken to mean promoting local 'buy-in' to internationally advocated institutional reforms when used in relation to peacebuilding programmes. ${ }^{23}$ However, what this buy-in entails and how it should be ensured remains debateable. For instance, should 'ownership' be based on local actors' responsiveness to, participation in or control over SSR decisions? ${ }^{24}$ Some analysts take it too far to argue that recipient countries should be 'appreciative of the benefits of policy measures'. ${ }^{25}$ For some others, on the other hand, ownership can only be realized if SSR measures are 'designed, managed and implemented by domestic actors rather than external actors. ${ }^{26}$ While the latter approach is privileged in donor discourses, in practice international actors remain reluctant to relinquish or share authority and control over the reform process. ${ }^{27}$ Most of the time, 'ownership' is reduced to generating

\footnotetext{
${ }^{20} \mathrm{OECD} / \mathrm{DAC}$, Security System Reform and Governance, 61.

${ }^{21}$ OECD/DAC, Monitoring the Principles, 10.

${ }^{22}$ lbid.

${ }^{23}$ Chesterman, 'Ownership in Theory', 4, 9.

${ }^{24}$ Ibid.; Nathan, 'Challenge of Local Ownership'.

${ }^{25}$ Bendix and Stanley, 'Deconstructing Local Ownership', 95.

${ }^{26}$ Nathan, 'Challenge of Local Ownership', 21.

${ }^{27}$ Donais, 'Inclusion or Exclusion?', 120.
} 
domestic support for donor-driven projects rather than the other way around. $^{28}$

Various factors underlie this reluctance to put locals in the driver's seat. One of them is the conviction that local actors (particularly civil society) lack the relevant SSR knowledge and expertise. ${ }^{29}$ From this conviction follows doubts about the ability of local agencies to agree on any single approach or desired outcome. ${ }^{30}$ Domestic elites' commitment to liberal democracy and improved democratic security governance also becomes a matter of concern, as reforms can be used as a means to strengthen their capacity to eliminate dissent or weaken political opponents. ${ }^{31}$

These evaluations can be criticized in several respects. First, domestic actors may not have the requisite knowledge and capacity to draft the needed SSR policies and plans especially after instances of violent conflict and governmental collapse; however, this is precisely what external actors are mandated to do - assisting with capacity-development rather than delivering these functions for them. ${ }^{32}$ In fact, civil society actors may well possess relevant expertise but their suggestions are often ignored or go unacknowledged..$^{33}$ Second, free and open contestation of policies and interests is an integral component of democracy that underpins SSR. ${ }^{34}$ Third, donors' perception or treatment of local actors as being 'incapable' or 'illiberal' leads to a contested reform process characterized by growing resentment and resistance since reforms are regarded as externally imposed solutions. ${ }^{35}$ Lastly, utilizing local knowledge and resources requires appreciation of indigenous practices and customs. However, it is important to recognize that local communities are contested 'sites of heterogeneity' and idealised interpretations of the local as 'benign' are misleading. ${ }^{36}$ It is equally misguided to assume that every elite in a host country is 'illiberal' or local civil society organizations are 'ineffective'. Illiberal elites can be compromised with the help of liberal elites. Local individuals and organizations can be very effective when it comes to raising awareness about certain issues or to disseminate the liberal values the UN and other international actors support. ${ }^{37}$

Another recurrent theme in the 'ownership' literature is agency. While almost everyone agrees on the need for achieving 'country ownership' of SSR measures, there is a lack of consensus on who exactly constitutes 'local

\footnotetext{
${ }^{28}$ Nathan, 'Challenge of Local Ownership', 21.

${ }^{29}$ Bendix and Stanley, 'Deconstructing Local Ownership', 98-9.

${ }^{30}$ Nathan, 'Challenge of Local Ownership', 22.

${ }^{31}$ Donais, 'Inclusion or Exclusion', 121.

${ }^{32}$ Nathan, 'Challenge of Local Ownership'.

${ }^{33}$ Bendix and Stanley, 'Deconstructing Local Ownership', 99.

${ }^{34}$ Nathan, 'Challenge of Local Ownership', 22.

${ }^{35}$ Von Billerbeck, 'Local Ownership and UN Peacebuilding'.

${ }^{36}$ Mac Ginty, 'Where Is the Local?'; see also Richmond, 'De-Romanticising the Local', 847.

${ }^{37} \mathrm{I}$ am grateful to my research assistant Mr. Levent Ozan for bringing these points to my attention and allowing me to incorporate them into this article.
} 
stakeholders' and what specifically they are supposed to 'own'. ${ }^{38}$ As a policy recommendation, the engagement of all government bodies and inclusion of larger segments of society including the poor, women, children and other vulnerable groups are singled out as a necessary condition for successful SSR outcomes. ${ }^{39}$ Facilitating the representation of society at large or 'liberal ownership' promises a more democratic, equitable and reliable peacebuilding strategy that fits the UN's normative agenda of constructing a liberal political environment. In practice, however, it is not deemed efficient in attaining short-term operational objectives such as the disarmament of belligerents, reconstruction of the physical infrastructure, repatriation of refugees and organization of elections. ${ }^{40}$

Involving challenging long-term mandates of conflict transformation such as building functioning institutions and consolidating democratic practices, peace operations also seek to achieve behavioural and attitudinal change through encouraging the engagement of local actors including former combatants, political elites, bureaucrats, community groups and other social actors who are concerned with the extent to which their interests are represented and their participation is enabled. ${ }^{41}$ An effective delivery of these transformative objectives requires the exercise of power by international actors in ways that encourage local 'buy-in' to peacebuilding projects and facilitate handover of political responsibilities to domestic institutions in a timely manner. ${ }^{42}$ Therefore, legitimacy becomes a critical factor in generating local compliance because the rules or norms institutions issue are not complied as a result of externally imposed stimuli (i.e. sanctions of punishment or rewards) but an 'internal sense of moral obligation' ${ }^{43}$ In addition to compliance, it also motivates cooperation between locals and a peace operation whose ability to shape the behaviour of local actors and achieve its transformative responsibilities is dependent on the degree to which it is perceived to be 'right, fair, and appropriate in the local context'. ${ }^{44}$ This makes legitimacy 'more than just another source of power' as it enables the power of international actors which they develop from other 'currencies of power' such as coercion and inducement. ${ }^{45}$ However, legitimacy, being an inter-subjectively constituted process, also creates constraints on institutions whose claim to legitimacy can be rejected by actors based on their perceptions of effectiveness and appropriateness. ${ }^{46}$ Taken altogether, these operational limitations arising from tensions

\footnotetext{
${ }^{38}$ Martin and Wilson, 'Security Sector Evolution'.

${ }^{39}$ UN, 'Securing Peace and Development'.

${ }^{40}$ Von Billerbeck, 'Local Ownership and UN Peacebuilding'.

${ }^{41}$ Whalan, How Peace Operations Work.

${ }^{42}$ lbid.

${ }^{43}$ Gippert, 'Exploring Local Compliance', 58.

${ }^{44}$ Whalan, How Peace Operations Work, 76.

${ }^{45}$ Ibid., 63.

${ }^{46}$ Gippert, 'Exploring Local Compliance'.
} 
between the long-term requirements of overly ambitious tasks and the shortterm priorities of international actors searching for exit strategies create an 'ownership dilemma'. ${ }^{47}$ This is why the reform process is most of the time confined to the participation of ruling elites and security professionals who are thought to have the needed SSR expertise and capacity. ${ }^{48}$ This way of conceiving 'locals' implies the presence of supposedly united actors and institutions around shared security goals and interests. ${ }^{49}$ A closer look into the domestic policy landscape, on the other hand, reveals how different social groups including state actors with competing agendas and relative capabilities produce and reproduce shifting coalitions and networks of interests to secure their access to political power and wealth. ${ }^{50}$

As noted earlier, SSR is a highly sensitive political process as it entails the engagement of foreign actors in security and defence affairs in the host state and changing domestic dynamics of power through rearranging the way in which political power is distributed and exercised along democratic lines. The language of 'ownership' enables external donors to gain access to these sensitive areas in conflict-affected countries ${ }^{51}$ and mask the extent of power and influence they exert over domestic policy making without any accountability to the local population through casting their role as facilitators of democratic self-governance. ${ }^{52}$ It also helps legitimize their intrusive international engagement in the domestic sphere through a promise of a more human-centric conflict transformation agenda. ${ }^{53}$ For instance, promoting 'community empowerment' occupies a central place in peacebuilding discourses. Multimillion dollar projects are executed by local personnel in specific local communities; however, the real power resides with donors who provide the money and determine 'what the local is' and which concepts and strategies should be pursued. ${ }^{54}$ Rather than producing real human security outcomes for the target populations, these seemingly locally driven projects are co-opted to perpetuate the hierarchies of power. The host government acts more accountably to foreign donors than their own citizens, many of whom are distanced from internationally regulated governing institutions and continue to live in poverty and under threats of renewed violence. ${ }^{55}$

International frameworks of regulation and monitoring take different forms ranging from the placement of foreign officials as co-workers or line

\footnotetext{
${ }^{47}$ Whalan, How Peace Operations Work, 32.

${ }^{48}$ Gordon, 'Security Sector Reform', 129.

49 Ibid.; Bendix and Stanley, 'Deconstructing Local Ownership', 96.

${ }^{50}$ For a detailed analysis of competing societal interests in the context of Timor-Leste's security sector development process, see Sahin and Feaver, 'Politics of Security Sector Reform'.

${ }^{51}$ Bendix and Stanley, 'Deconstructing Local Ownership', 94, 101.

${ }^{52}$ Chandler, Empire in Denial.

${ }^{53}$ Mac Ginty, 'Where Is the Local?'

${ }^{54}$ Ibid.

${ }^{55}$ Chandler, Empire in Denial.
} 
managers in critical state institutions such as the police service, finance and justice departments to overseas aid programmes and organizational membership processes conditioned on the adoption of certain policies and reforms. ${ }^{56}$ It is, however, misleading to describe the interactions between intervening and domestic parties in homogenized or dualistic terms as occurring between allpowerful foreigners and all-disadvantaged, submissive locals. This is not to 'romanticize' the capacity and agency of the local as Mac Ginty and Richmond warn against. It is rather to point out that power, as noted in the introduction, is not something that one actor possesses and another lacks completely. Power, following Elias, rather arises from a 'relational' process that is characterized by asymmetries and interdependencies, as actors perform a 'function' for each other.

When this notion of power as a relational attribute is applied to the analysis of the policy spaces in intervened states, it becomes clear that the power-based relationships between foreign peace-builders and local political groups are determined by their agendas rooted in mutual dependencies. In this relationship, the former are concerned with the execution of peacebuilding programmes which requires the consent of local elites, while the latter seek to attain international support to achieve their ultimate political aspirations. The policy sphere turns into a site of mutually reinforcing agendas where international and local political objectives are brought into some sort of mutually supporting balance. Practices of positive remarks and praising become a key feature of this process. International agencies need success stories for the justification and legitimization of their presence and the policy reforms they advocate. Loudly praised accounts of developing local performance and publically expressed stories about progress with stability and democratic governance serve to continue with implementation of existing peacebuilding agendas and strategies, and provide a convincing reference point for promoting neoliberal policy agendas in other fragile or conflict-affected countries.

This is why many recipient governments avoid explicitly rejecting internationally advocated reform programmes, as they do not want to be deprived of a variety of opportunities these programmes carry such as gaining access to financial resources, international recognition and legitimacy. Rather than saying 'no' to international agencies, they express their commitment to a democratic security sector and other institutional reforms at the policy level, while appropriating these reforms into existing power structures and practices. Rather than a liberal democratic transformation, the emerging social environment under these circumstances becomes one of 'hybrid peace' which, according to Boege ${ }^{57}$ and Richmond, ${ }^{58}$ refers to a situation in which externally

\footnotetext{
${ }^{56}$ Chandler, International Statebuilding.

${ }^{57}$ Boege, 'Hybrid Forms of Peace'.

${ }^{58}$ Richmond, 'Resistance and the Post-Liberal Peace'.
} 
promoted liberal democratic policies and principles co-exist with illiberal and undemocratic practices and norms. Hybrid forms of peace emerging from local agency in an attempt to resist externally prescribed policy measures often evolve through different strategies of resistance including opposition, limited co-operation, co-option or manipulation of newly crafted institutions, and the articulation of public demands for the localization of governance structures as manifested in the 'Kosovanization', 'Timorization' and 'Afghanization' campaigns initiated against state-building administrations. ${ }^{59}$ Examples of peacebuilding as resistance also include the SSR efforts in the Democratic Republic of Congo and Rwanda where local actors managed to 'transform' ${ }^{\text {'60 }}$ or keep the reform process in such a way that enabled them to 'claim local ownership, radically different from the discursive and rhetorical local ownership usually found in these circumstances'. ${ }^{61}$

\section{The analytical framework to apply to the study of internationally promoted ssr in fragile settings}

Sherry Arnstein's conceptualization of a 'ladder of citizen participation', ${ }^{62}$ which Wilson refers to in her analysis of the 'local ownership' of the UNassisted reform of the East Timorese police, ${ }^{63}$ offers a useful analytical framework to examine how 'ownership' takes form in the context of internationally promoted institutional reforms and governance models. In her 1969 seminal work focused on urban transformation participation in the USA, Arnstein suggests that genuine public participation requires reorganization of power that enables citizens to get included in determining how information is distributed, policies and programmes are set and managed. Noting that ' $[\mathrm{t}]$ here is a critical difference between going through the empty ritual of participation and having the real power needed to affect the outcome of the process, ${ }^{64}$ Arnstein develops an eight-rung ladder to distinguish between different degrees of participation (Figure 1): ${ }^{65}$

1. Manipulation: No participation occurs. The objective is not to enable people to participate but 'educate' them and 'engineer' their support for pre-determined outcomes. In the name of participation, citizens are placed on rubberstamp committees, advised and persuaded by officials.

2. Therapy: It is non-participative. Citizens are involved in extensive activity but the objective is to 'cure' their 'pathology' rather than changing the structural conditions that permit such 'pathologies' to occur. In doing

\footnotetext{
${ }^{59}$ Richmond, A Post-Liberal Peace.

${ }^{60}$ Rayroux and Wilen, 'Resisting Ownership'.

${ }^{61}$ Wilen, 'Hybrid Peace', 1331.

${ }^{62}$ Arnstein, 'Ladder of Citizen Participation'.

${ }^{63}$ Wilson, Smoke and Mirrors, 19-25.

${ }^{64}$ Arnstein, 'Ladder of Citizen Participation', 216.

${ }^{65}$ Ibid., 217-23.
} 


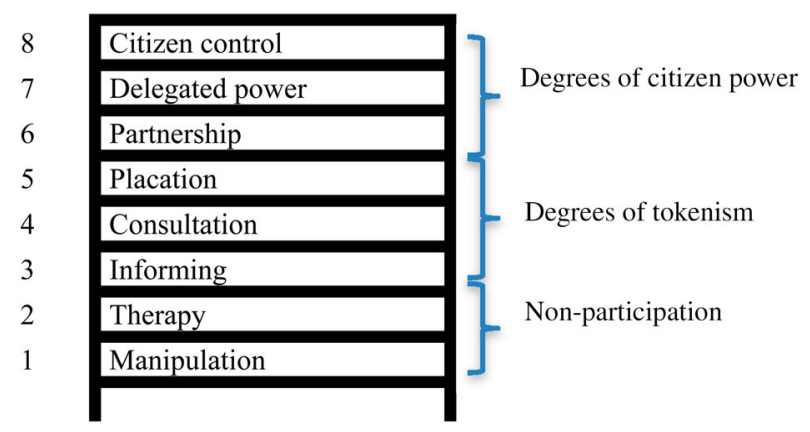

Figure 1. Arnstein's ladder of citizen participation. Arnstein, 'A Ladder of Citizen Participation', 217, reprinted by permission of the American Planning Association, www. planning.org.

so, frustrations are appeased and public support for an already decided strategy is secured.

3. Informing: It constitutes an important first step towards legitimate public participation. However, there exist no real channels for feedback and negotiation, as the flow of information takes place in one direction - from officials to citizens. The use of media tools, brochures and posters exemplifies this tokenistic level of involvement.

4. Consultation: Citizens are provided with feedback mechanisms such as attitude surveys, neighbourhood meetings or public inquiries. However, it may still be a window dressing ritual, if citizens are not given any assurance that their ideas will be accepted or taken into account.

5. Placation: Citizens begin to exercise some degree of influence as they are enabled to join the planning process but tokenism is still apparent. This is exemplified by the placement of a few hand-picked 'worthy' have-nots on boards of community action or housing. They can advise or make recommendations about a proposed plan but traditional power holders holding majority of seats still retain the right to accept or reject the advice.

6. Partnership: Power is redistributed through negotiation between citizens and power holders. Planning and decision-making responsibilities are shared through joint committees and dispute resolution mechanisms such as bargaining processes. Once the ground rules are established through mutual concessions; they cannot be changed unilaterally.

7. Delegated power: Citizens exercising dominant decision-making authority over a particular programme as a result of negotiations with officials. The public holds power to assure accountability of the programme to them. For example, residents having majority of decision-making seats on model city policy boards or community action agencies operating with the authority and resources to prepare planning programmes, hire (and fire) their own staff. 
8. Citizen control: Citizens holding authority to govern a programme and being in full charge over its planning, policy-making and managerial aspects. Neighbourhood corporations with no intermediaries between them and the source of funds can be given as an example.

Using Arnstein's 'ladder of participation' as an analytical tool, the following section elaborates on Kosovo's SSR experience by reference to the patterns of power relationships between national and international actors over time.

\section{The process of security sector development in Kosovo}

Kosovo's experience with security sector development can be examined on the basis of three timeframes. The first period which covers between the establishment of the United Nations Interim Mission in Kosovo (UNMIK) in June 1999 as per Security Council Resolution 1244 and adoption of 'standards before status' policy demonstrates combined elements of manipulation, therapy and informing. Manipulation is evidenced by the formation of seemingly participatory transitional institutions such as the Kosovo Transitional Council (KTC). The KTC was created in July 1999 as a consultative body to give Kosovars an 'opportunity for direct input into the decision-making process of UNMIK' ${ }^{66}$ In reality, however, it had no substantial authority, as all legislative and executive powers resided with the head of the Special Representative of the UN Secretary-General (SRSG), who also appointed KTC members. Therapy becomes clear in the initiatives taken by Bernard Kouchner, the first SRSG, to appease the frustrations of some Albanian parties that felt excluded from the political process. This included the enlargement of KTC membership from 12 to $34^{67}$ and adoption of the law in force prior to the revoking of Kosovo's autonomy in March 1989 as the applicable law ${ }^{68}$ in an attempt to dissolve all existing 'parallel institutions' of security, revenue collection and public services, and encourage disgruntled Albanian parties' participation in the UNMIK-supervised institutions. ${ }^{69}$ The decision to change the applicable law is striking in terms of illustrating power as being a relational attribute of actors deriving from mutual dependencies. It was taken to secure the cooperation of Albanians with the international administration following their universal boycott of the courts that left the judiciary in almost com-

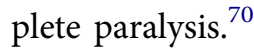

\footnotetext{
${ }^{66}$ UNMIK, 'UNMIK Convenes First Meeting'.

${ }^{67} \mathrm{UN}$, 'UN Interim Administration Mission'.

${ }^{68}$ UNMIK, 'UNMIK Regulation No. 1999/24'.

${ }^{69}$ For details, see David Holley, 'Kosovo Factions' Differences Apparent at Council Meeting', Los Angeles Times, 22 Aug. 1999.

${ }^{70}$ Yannis, 'Kosovo under International Administration', 34.
} 
Informing is evidenced by the prevailing patterns of one-way flow of communication (from UNMIK to locals) regarding general aspects of institutional structuring in the form of regulations the SRSG issued or pamphlets, TV/ radio programmes providing information on the internationally supervised local and parliamentary elections or on aspects of the agreements concluded with Kosovar leaders. One of the key agreements concerned the transformation of the KLA (Kosovo Liberation Army). NATO, entrusted with final authority over all aspects of security in Kosovo, was responsible for oversight of the demobilization of the KLA. The demobilization and transformation of the KLA was carried out according to the 'Undertaking of Demilitarization and Transformation' agreed between the NATO and KLA leaderships on 21 June 1999. While it was noted in the said agreement that the formation of a national army should be given 'due consideration' by the international community, the creation of a civilian emergency agency (known as the Kosovo Protection Corps, KPC) and a multi-ethnic police force (Kosovo Police Service, KPS) was pushed forward by international actors to transform the KLA. The KPC was modelled on the Sécurité Civile of France to provide emergency and reconstruction services in Kosovo and planned to consist of around 3,000 active duty personnel and 2,000 reservists that would be largely drawn from KLA ranks. ${ }^{71}$ The registration and subsequent screening of some 20,000 former guerrillas was carried out by the International Organization for Migration (IOM) by the end of $1999 .{ }^{72}$ It was formally constituted in January 2000 with the SRSG's appointment of its 46 key leaders and it reached its authorised strength of 5,052 (except most of the 500 slots reserved for minorities) in two months' time. ${ }^{73}$

In the absence of a Ministry of Interior Affairs, the construction of a professional, multi-ethnic police force was run by UNMIK's Justice and Police Pillar. The KPS designed as a force of 5,000-7,000 police officers was created in September 1999 with the establishment of a police school in north central Kosovo by the OSCE (Organization for Security and Cooperation in Europe), the lead organization for the institution-building component of UNMIK. In the first group, around 200 cadets selected from more than 19,000 applicants received a nine-week basic training at the KPC school followed by a 19 -week field training provided by UNMIK Police. ${ }^{74}$ As of mid-2001, around 4,000 candidates graduated from the KPS school, with the targeted quotas for minority and women participation (15 per cent for both) being achieved. ${ }^{75}$ Compared to the KPC which was not 'owned'

\footnotetext{
${ }^{71}$ UNMIK, 'UNMIK Regulation No. 8'.

${ }^{72}$ International Organization for Migration (IOM), 'Kosovo Reintegration Efforts'; UNMIK, 'Kosovo Protection Corps'.

${ }^{73}$ UNMIK, 'Kosovo Protection Corps'.

${ }^{74} \mathrm{UN}$, 'Report of the Secretary-General on the United Nations Interim Mission', para. 44.

${ }^{75} \mathrm{O}^{\prime}$ Neill, Kosovo, 112.
} 
by minority communities due to its legacy as a successor to the KLA or an 'army in waiting', the KPS was widely regarded as the most successful part of UNMIK's mandate. ${ }^{76}$ However, the absorption of former KLA fighters into the police as a law enforcement agency remained a cause for concern regarding its professionalism and neutrality among Serbs and others. ${ }^{77}$

All the security sector development initiatives taken during the initial phase were placed beyond the authoritative realm of local institutions, including the Provisional Institutions of Self-Government (PISG) established by the Constitutional Framework that entered into force in May 2001. ${ }^{78}$ The division of responsibilities between 'transferred' and 'reserved' powers further illustrates practices of therapy. Through creating provisional institutions operating outside the purview of Belgrade, UNMIK allayed Albanians' fear of return to Serbia and encouraged their cooperation. By retaining authority over key areas, the international administration simultaneously sought to mollify the Serbs' concern that Kosovo was heading towards independence. Administrative responsibilities over seemingly not-too-sensitive areas such as culture, youth, health, agriculture and environmental protection were devolved to the Albanian-dominated PISG. Powers over sovereignty-related issues such as policing and the judiciary, external relations and the administration of public and socially owned enterprises, were still vested with the SRSG. However, the slow transfer of administrative competencies fuelled tensions between UNMIK and Kosovo Albanian elites. For them, international staff members most of whom were posted several times in Kosovo preferred staying longer there, as it was much safer than other fragile or war-affected countries and its geographical location made travelling to their home countries much easier. The portrayal and treatment of Kosovo as an 'emergency' or 'crisis' situation would thus be favourable, as it provided a powerful rationalization for their continued presence, while the actual objectives of reformation and self-government capacity would be delayed. ${ }^{79}$

The second phase covers SSR initiatives undertaken between UNMIK's official adoption of the 'standards before status' policy in December 2003 and the Kosovo Parliament's unilateral declaration of independence in February 2008. The 'standards' policy conditioned the opening of the status negotiations on demonstrated progress in eight areas including functioning democratic institutions, rule of law, freedom of movement, refugee return, economic development, property rights, dialogue with Belgrade and the KPC. ${ }^{80}$ However, the benchmarks approach perceived as another delaying tactic by the majority Albanians, waiting for the international community

\footnotetext{
${ }^{76}$ Heinemann-Gruder and Paes, 'Wag the Dog'.

${ }^{77}$ Rees, Security Sector Reform, 20.

${ }^{78}$ lbid.

${ }^{79}$ Personal communication with a member of the expatriate community in Pristina, Sep. 2015.

${ }^{80}$ 'Standards for Kosovo'.
} 
to recognize their independence declared in 1991, failed to deliver its anticipated outcomes in terms of democratic governance capacity-development. ${ }^{81}$

As discussed earlier, it is misguided to assume the locals to be a homogenous community that passively complies with the 'ownership' of externally produced policies. They use different means to resist, reject or transform the political agenda they are imposed to 'own'. This is exemplified by the March 2004 violence which made it abundantly clear that the status diplomacy could no longer be delayed. During the two-day riots, 11 Albanians and 8 Serbs were killed, more than 900 people were wounded, around 4,500 people were displaced, over 700 properties belonging to minorities were damaged, and dozens of UNMIK and Kosovo Force (KFOR) vehicles were set on fire. ${ }^{82}$ In a detailed report submitted to the UN Security Council in November 2004, Kai Eide, a top Norwegian diplomat appointed as Special Envoy of the Secretary-General, called for 'a more dynamic standards policy with achievable priorities', as the existing strategy based on the 'implementation of highly ambitious' benchmarks was an 'untenable' approach that lacked credibility. ${ }^{83}$ Following a comprehensive standards implementation review, Eide recommended commencement of status talks a year later. ${ }^{84}$

The talks mediated by former Finnish President Martti Ahtisaari, acting as UN Secretary-General's Special Envoy, were held in Vienna throughout 2006, with no mutually agreed solution reached. Ahtisaari announced his internationally endorsed proposal in February 2007. The Ahtisaari plan proposed the separation of Kosovo from Serbia and deployment of a European Union-led international civilian presence to replace UNMIK. ${ }^{85}$ Kosovo, in other words, would be legally recognized as sovereign, while its domestic self-government capacity component would be strengthened by international agencies. This administrative arrangement, referred to as 'supervised independence', was modelled on the protectorate-like administrative system put in place in Bosnia and Herzegovina following the Dayton Peace Accord. The Ahtisaari plan also sanctioned the development of a national security sector through creating new institutions such as the Kosovo Security Force (KSF), Kosovo Security Council (KSC) and the Kosovo Intelligence Agency (KIA), while recommending the presence of the NATO-led security force staying for an unspecified period of time. ${ }^{86}$ The proposed actions would be structured upon the recommendations made in the internal security review conducted in 2005-06 to provide a road map for Kosovo's future security architecture. ${ }^{87}$

\footnotetext{
${ }^{81}$ ICG, 'Collapse in Kosovo', 2.

${ }^{82} \mathrm{UN}$, 'Report of the Secretary-General on the United Nations Interim Administration Mission', para. 3.

${ }^{83}$ Eide, 'Report of the Situation in Kosovo'.

${ }^{84}$ Eide, 'Comprehensive Review'.

${ }^{85} \mathrm{UN}$, 'Report of the Special Envoy'.

${ }^{86}$ Ibid., Annex XI.

${ }^{87}$ Anthony Cleland Welch et al., Kosovo Internal Security Sector Review.
} 
It is noted in the review document that a holistic and inclusive approach was taken to deliver a comprehensive threat analysis based on the methodology devised by the British Government's Security Sector Development Advisory Team (SSDAT), ${ }^{88}$ which undertook a 'scoping mission' in March 2005 to provide recommendations for the structure, objectives and work plan of Kosovo's internal security review. ${ }^{89}$ However, the lead author of the said review writes elsewhere that upon SSDAT advice the process was in effect directed by an internationally dominated steering committee consisting of high-level representatives from UNMIK, the PISG, religious and community leaders, even though Soren Jessen-Petersen, SRSG at the time, was reportedly in favour of 'a review by and for the people of Kosovo'. ${ }^{90}$ Indeed, even the idea of examining the internal security situation in Kosovo was introduced by a British general who witnessed the UK-led security sector reform project in Sierra Leone, and persuaded Jessen-Petersen on the need for a similar process in Kosovo before the status talks. ${ }^{91}$ The operating capacity of the steering committee was also reportedly hampered by the resistance from both Serbs and some Albanian political parties from the beginning. While the former refused to be part of what they perceived to be a predominantly Albanian and international community-oriented body, the latter viewed it as being biased towards a particular party (Alliance for the Future of Kosovo Party), which held the majority of the security sector-related ministries. ${ }^{92}$

When Arnstein's 'ladder of participation' is applied to the analysis of the review process, elements of ritual engagement can be identified, including therapy, placation, informing and consultation. First, the review project came as a problem-solving initiative following the March 2004 violence to outline and 'cure' the internal security 'pathologies' in the UN-run territory (therapy). It was proposed by a foreign general based on his prior experience in another country and endorsed by UNMIK and other international actors seeking to rescue the stagnated relations with the local political leadership through a holistic and 'locally owned' approach to institutional capacity building. As exemplified by Jessen-Petersen's remarks on the catalysing role of the violent riots: 'March 2004 was a message to all of us, the locals and the internationals, that we had to change directions and more diligently pursue security sector reform in Kosovo. ${ }^{93}$ Second, the review was managed by a high-level steering committee that included hand-picked Kosovar agencies while executive responsibilities resided with international agencies (placation). However, the process was boycotted by both Serbs and some Albanian

\footnotetext{
${ }^{88}$ Ibid., xiii.

${ }^{89}$ Cleland Welch, 'Security Sector Review in Kosovo', 47.

${ }^{90}$ Cleland Welch, 'Appraising the 2006 Kosovo Internal Security Sector Review'.

${ }^{91}$ lbid.

${ }^{92}$ lbid.

${ }^{93}$ Quoted in Bajraktari and Parajon, 'Future of Kosovo's Security Sector'. http://www.usip.org/publications/ the-future-of-kosovos-security-sector (accessed June 9, 2016).
} 
political groups. Third, the organization of town hall meetings and use of media tools such as TV and radio programmes, social media and billboards for greater public awareness and deeper public understanding of security issues $^{94}$ exemplify the one-way exchange patterns Arnstein refers to in the context of informing activities. Fourth, it remains unclear to what extent the feedback ordinary Kosovars provided through consultative mechanisms such as surveys and the 'have your say bus' travelling across villages and urban areas was taken into consideration by power holders, as decisionmaking authority over policy recommendations resided with international agencies (consultation). This is reflected in the neglect of the local demands for a national defence force ${ }^{95}$ and the recommended creation of a lighter force (i.e. the KSF), as later endorsed in the Ahtisaari plan, which avoided reference to a Kosovo army. Fifth, the review process which purportedly cost over US $\$ 2$ million, was obstructed by competing political agendas, developing in parallel with status talks and a separate bilateral security review undertaken by the USA. ${ }^{96}$ Lastly, there was little public awareness about the findings and recommendations of the review report as it was distributed to policy circles only and quickly disappeared from public view (informing) ${ }^{97}$

The final phase is focused on the developments relating to Kosovo's strategic security orientation since the declaration of independence. The SSR-related activities undertaken during this period are characterized by a mixture of consultation, informing, partnership and delegated power. The institutional reform process has developed on the basis of the Ahtisaari plan, which was incorporated into the constitution that entered into force in June 2008. This included the disbanding of the KPC and its transformation into the KSF. Established as a lightly armed small force responsible for delivery of civil protection and disaster response tasks, the KSF can be deployed for overseas peace operations, humanitarian operations and training and exercise programmes. ${ }^{98}$ It is trained by NATO and, according to a senior government official, the KSF is currently an institution somewhere 'between a civilian security force and an army [... ] [that is planned to] transform into an army in the medium term', implying receipt of military training. ${ }^{99}$ The government's SSR measures also included a policy-planning process to formulate a national security strategy (NSS) under the leadership of the newly created Kosovo Security Council (KSC). However, the process

\footnotetext{
${ }^{94}$ Cleland Welch et al., Kosovo Internal Security Sector Review, 5.

${ }^{95}$ It is noted in the review document that 'should the international community attempt to deny an independent Kosovo its own defence force, action would be taken to create such a force. The ISSR [Internal Security Sector Review] further believe that such an outcome would work against the progress that has been made to bring security to Kosovo and the region as a whole.' Ibid., xviii. See also, ibid., 140.

${ }^{96}$ Saferworld, 'Internal Security Sector Review'.

${ }^{97}$ Interview with Florian Qehaja, Director of Kosovar Centre for Security Studies, Pristina, Mar. 2015.

${ }^{98}$ 'Law No. 04/L-177 on Overseas Deployment'.

${ }^{99}$ Interview, Ministry of Kosovo Security Force, Pristina, Jul. 2015.
} 
was reportedly obstructed by the highly interventionist approach of the International Civilian Office (ICO) ${ }^{100}$ which was established as a supporting office for the International Civilian Representative (ICR) mandated to 'supervise' the capacity-development of Kosovo's institutions including the security sector, as stipulated in the Ahtisaari plan (consultation). From the perspective of the ICO officials, the strategic planning, it is argued, should have focused on general aspects of 'human security' rather than the 'real security risks and threats' facing the country such as northern municipalities' refusal to recognize Pristina's authority, as discussion of these issues was deemed to be 'detrimental to security and stability'. ${ }^{101}$ The first draft prepared by local experts was arguably completely rewritten by the ICO staff and submitted to the KSC Secretariat towards the end of $2009^{102}$ (informing). It was not even deliberated in the Parliament despite this being required by Kosovo's constitution. ${ }^{103}$ Additionally, it has neither been published nor put into implementation, even though the government, under strong international pressure, announced the document was approved in 2010. ${ }^{104}$ Resisting the externally imposed strategies in the NSS by ignoring or not implementing the document, the Thaci Government declared in early 2012 that a new strategic security review would be initiated, leading to both the 2006 UK-managed review report and the 2010 ICO'advised' strategic document being shelved indefinitely.

Due to operational delays arising from a lack of clear timeline, changing institutional roles, weak inter-agency coordination and budget deficits, the review was eventually completed in March 2014 with the government's approval of its produced results. ${ }^{105}$ The published end product entitled Analysis of the Strategic Security Sector Review of the Republic of Kosovo outlines the country's security priorities and the role of its security institutions from a state-centric, defence-focused perspective. ${ }^{106}$ It sets out safeguarding Kosovo's sovereignty and territorial integrity as the primary security objective and formulates the creation of a national army towards this objective. Other security priorities include the gradual transfer of security and defence responsibilities from the NATO-led international security presence, development of 'good neighbourly relations' with Serbia, prevention of radical Islamist and fundamentalist groups' operations in the country, withdrawal of the foreign military and civilian presence and reducing poverty. ${ }^{107}$

\footnotetext{
${ }^{100}$ Blease and Qehaja, 'Conundrum of Local Ownership'.

${ }^{101}$ Ibid.

${ }^{102}$ Ibid.

${ }^{103}$ Interview, Gap Institute, Pristina, Jul. 2014.

${ }^{104}$ Forum for Civic Initiatives (FIQ) et al., 'New Kosovo Security Strategy Formulation'.

${ }^{105}$ Derks-Normandin, Linking Peace and Durable Solutions, 15; Cleland Welch, 'Kosovo's Home-Grown SSR'.

${ }^{106}$ Government of Republic of Kosovo, Analysis of the Strategic Security Sector Review.

${ }^{107}$ Interview, Ministry of Kosovo Security Force, Pristina, Jul. 2014.
} 
The process was undertaken under strong US influence focusing on regional political issues and security challenges. ${ }^{108}$ It was carried out by security professionals and directed within closed circles through a ministerial-level steering committee, with almost no civil society participation (informing). The committee did not involve any representatives from the Serbian community and was chaired by the Minister of the KSF rather than the KSC which is constitutionally mandated to provide recommendations for security policies and strategies. ${ }^{109}$ From a methodological perspective, the 2014 review was clearly a product of a less inclusive approach compared to the process in 2005-06. On the other hand, in terms of its 'outcomes' focusing on issues of internal and external sovereignty facing Kosovo in the post-independence period, the 2014 review might be said to be 'owned' more than the previously released one. ${ }^{110}$ The 2006 process, as discussed earlier, was based on broader public consultation initiatives including town hall meetings, surveys and the use of a 'have your say' bus, TV, radio and social media. However, the initiation, planning, execution and outcomes of the said process were all determined by UNMIK and other international actors. The 2012-14 review, on the other hand, was initiated and led by the Kosovo authorities that apparently chose to work with the US authorities to be able to facilitate their desired outcomes (partnership).

On the other hand, the government's envisioned army project, reportedly decided in consultation with NATO, ${ }^{111}$ has encountered delays in implementation since former Prime Minister Hashim Thaci's declaration in March 2014 that the KSF would be transformed into a regular defence force by $2019 .{ }^{112}$ One source of the surrounding delays is the international community's 'stability first' policy which has sought to prevent any initiatives that may potentially provoke a strong reaction from Serbia and Russia and disrupt the conditions of stability established in the Balkans region by the NATO intervention. ${ }^{113}$ In this regard, the position the USA and other key external actors will take in accordance with considerations of the regional balance of power will clearly determine the prospects of the planned transformation of the KSF into a national defence force. Four NATO members (Spain, Greece, Romania and Slovakia) have so far refused to recognize Kosovo and the KSF transformation is therefore potentially a divisive issue for the organization. Since its declaration in July 2013 that the KSF reached its full operational capacity to assume more responsibility for providing security in Kosovo, NATO appears to have confined its role to training and capacity-development.

\footnotetext{
${ }^{108}$ Cleland Welch, 'Kosovo's Home-Grown SSR'.

${ }^{109}$ Kosovar Institute for Policy Research and Development (KIPRED), Kosovo Security Sector Observer.

${ }^{110}$ Interview, Kosovar Centre for Security Studies, Mar. 2015.

111'Thaci: Pristina Has NATO's Approval'.

${ }^{112 ` K o s o v o ~ t o ~ C r e a t e ~ O w n ~ A r m y ' . ~}$

${ }^{113}$ Interview with Florian Qehaja, Director of Kosovar Centre for Security Studies, Pristina, Mar. 2015.
} 
For instance, in a joint press conference with Prime Minister Isa Mustafa during his visit to Pristina in January 2015, Secretary-General Jens Stoltenberg responded to the questions on the government's plans to create an armed force by reaffirming NATO's capacity-development responsibility: '[i]t's not up to NATO to decide how the security forces of Kosovo is developed. What we are doing is that we are doing capacity building for the Kosovo Security Forces within its present mandate. ${ }^{114}$ Through framing its role as one of technical and KSF transformation as a domestic affair of Kosovo, NATO seeks to maintain its own internal cohesion and keep the organization out of the surrounding political debates and controversies, thereby evading responsibility for any moves that may trigger regional instability.

Pristina authorities for their part, as it appears in the newsletters and annual reports released by the Ministry of Kosovo Security Force (MKSF), are using bilateral partnership frameworks to realize their desired outcome of transforming the KSF into an armed force and creating a Ministry of Defence responsible for its civilian oversight. In the 2014 annual report, for instance, it is noted that 'the MKSF and KSF [...] together with our friends from the United States have developed detailed plans and programmes that precede the process of evolution of the KSF in[to] the Armed Forces' ${ }^{115}$ In a newsletter released in November 2015, KSF Minister Haki Demolli states that ' $[w]$ e presented our needs to our partners and received practical and wellthought-out proposals'. ${ }^{116}$ However, it remains unclear as to what specially these needs were and how they were identified, as there has been no report or document relating to the needs assessment of the KSF development publically shared yet.

One thing is clear though. The Kosovo leadership aspires to assert full sovereignty and exercise dominant decision-making authority over its domestic affairs through creating a defence force that will assume the responsibility of providing security from the NATO-led KFOR. The government's planned security architecture, in other words, illustrates what Arnstein describes as delegated power. Although the ICO's departure in September 2012 was presented to the domestic audience as the end of 'supervised independence' established by the Ahtisaari plan, in reality the country has remained dependent on a large civilian and military presence for its security and institutional development. While the EU's rule of law mission (EULEX) retains certain executive powers (such as EU judges and prosecutors performing judicial proceedings in the north of the country), ${ }^{117}$ Kosovo's external

\footnotetext{
${ }^{114}$ NATO, 'Joint Press Point. http://www.nato.int/cps/en/natohq/opinions_116807.htm?selectedLocale=en (accessed June 9, 2016).

${ }^{115}$ Ministry of Kosovo Security Force, Annual Report 2014, 5.

${ }^{116}$ 'Ministry for the Kosovo Security Force Newsletter'. http://www.mksf-ks.org/repository/docs/ Newsletter_November_2015_Frame.pdf

${ }^{117}$ Under its current mandate, international judges and prosecutors are 'embedded' in Kosovo institutions, and they will not take on new cases and transfer competencies to the Kosovo judicial system with the
} 
protection as well as internal security in the Serb-dominated northern part of the Ibar river is provided by NATO troops. Kosovo's claim to sovereign statehood has further been undermined by Belgrade's de facto control over northern municipalities and the opposition of Serbia, Russia, Spain, China and many others to accept its independence, even though it has so far been recognized by more than 100 member states of the UN. The security situation in the north characterized by inter-ethnic tensions, a lack of rule of law, restricted freedom of movement and organized crime remains a serious cause for concern for many Albanians, while Serbia's approach towards Kosovo is one of the widely identified external security threats in public surveys. ${ }^{118}$ The surveys also found that the KSF is the most trusted institution ${ }^{119}$ and its transformation into an armed force appears to be the most supported policy initiative by the citizens of Kosovo. ${ }^{120}$ Strengthening the ability of its own institutions and taking control of security matters are therefore among the key strategic priorities for the government to exercise delegated power.

On the other hand, it is widely believed by local analysts that the ratification of the government's proposed constitutional arrangements to allow for the planned transformation process, which requires the affirmative votes of the Serbian members of the Kosovo Parliament, can only be made possible through international intervention. ${ }^{121}$ The formation of Kosovo's national army, which has received strong opposition from Belgrade, has been at the centre of a political bargaining between the Kosovo Albanian and Serbian parties. ${ }^{122}$ Its use as political leverage was apparent during the political process leading to the creation of a special court for trial of war crimes allegedly committed by the KLA, which is viewed as an outcome of increasing Western pressure for a concession by both Albanian and Serbian deputies in exchange for their preferred policy outcomes. ${ }^{123}$ The transformation of the KSF requires a double majority in the Parliament, meaning the approval by two-thirds majority of the 100 Kosovo Albanian MPs plus by two-thirds of the 20 ethnic minority MPs in favour of the proposed constitutional amendments. Serb MPs have so far been reluctance to endorse the proposed amendments and Pristina authorities are reportedly considering alternative options such as changing the Law on the Kosovo Security Force only. While it remains to be seen how this political process will evolve, the current negotiations

exception of the northern part of the country where 'EULEX will remain in charge of judicial proceedings until the EU Facilitated Dialogue between Pristina and Belgrade brings a solution for the judiciary'. 'Short History of EULEX', http://www.eulex-kosovo.eu/?page=2,44,197 (accessed 12 Aug. 2015).

${ }^{118}$ Kosovar Centre for Security Studies, Kosovo Security Barometer, Dec. 2014.

${ }^{119}{ }^{1}$ Kosovo Police and KSF Most Trusted Institutions, KIPRED Survey Finds', http://www.kosovapress.com/ en/nacional/kipred-nxjerr-policine-dhe-fsk-ne-si-me-te-besueshmet-48599 (accessed 26 Aug. 2015).

${ }^{120}$ Kosovar Centre for Security Studies, Kosovo Security Barometer, Dec. 2015.

${ }^{121}$ 'The Establishment of Kosovo'.

${ }^{122}$ Hajdari, 'Kosovo Serbs MPs Say "No"'.

${ }^{123}$ 'Draft Law on the Armed Forces'; 'Kosovo MPs to Vote'; Ezik, 'Under Western Pressure'. 
between the government and international authorities over the formation of a national army and NATO withdrawal illustrate attempts to redistribute power (partnership) and exercise dominant decision-making authority over defence and security that traditionally fall under state sovereignty (delegated power).

\section{Conclusion}

SSR implementation in 'fragile' or 'conflict-affected' countries is a sensitive process. It goes beyond technical tasks and challenges (such as the planning and delivery of training programmes and the availability of skills, expertise and funding) to include political difficulties. Donors have advocated institutional reforms aiming to instil and consolidate liberal democratic principles and practices of accountability, transparency, civilian control of armed forces and the rule of law that in effect require redesigning the way in which political power is distributed and exercised. Creating winners and losers, the reform process may trigger instability and even the resumption of violence. The (direct or indirect) involvement of foreign actors in processes of drafting security and defence-related laws and policies also often creates tensions between donors and national governments. In addition to being a politically sensitive exercise, SSR implementation has so far been characterized by uneven results. Despite gradual improvements in public security conditions, many 'fragile' or 'conflict-affected' countries remain dependent on the presence of foreign military and civilian agencies for security provision and institutional capacity-development. It is against this background of political sensitivities and policy failures that the notion of promoting 'ownership' through locally driven or contextually sensitive approaches has gained currency and been utilized by both external donors and domestic actors to legitimize their policies and improve outcomes.

Outcomes, on the other hand, are determined by power to influence decisions and their implementation. Both outcomes and power are a matter of degree and they evolve through actors' interactions in a relational process. Actors' mutual dependencies determine the degree of power they exercise. Drawing upon this conceptual framework which takes actors' changing motivation and capacity as a key unit of analysis, in this article I have sought to demonstrate how different outcomes of SSR 'ownership' have emerged in Kosovo over time as a result of different patterns of, and changes in, power relationships between domestic and international actors. Indeed, Kosovo's experience is illustrative of showing how the principle of local ownership embedded in the discourses of international and domestic actors is in practice characterized by their acts of legitimization and appropriation in an attempt to achieve their preferred outcomes in a dynamic context. 
Legitimacy has constituted an important source of power for both Kosovar and international actors involved in a relationship of mutual dependencies. For Albanian elites, independence from Serbia could only be achieved with international support for their claim to self-determination. The effectiveness of the international engagement in Kosovo, on the other hand, was dependent on the cooperation of local elites in the work of UNMIK. The SSR activities undertaken during the initial phase (1999-2003) reflects this mutually reinforcing agenda. The formation of several transitional institutions such as the KTC and the PISG exemplifies international agencies' efforts to encourage leading Albanian parties' participation in the process of institutional restructuring. While being described as channels for participatory decision making by UNMIK officials, these institutional mechanisms were in reality marked by different elements of ritual engagement including manipulation, therapy and informing. They had no real decision-making authority as all the executive responsibilities were vested with UNMIK. The concentration of formal powers in international agencies, however, does not necessarily mean that the Kosovo actors were completely powerless or lacked resources to reject or transform the internationally imposed policy frameworks. The abolition of the 'standards before status' policy and the opening of status talks following the 2004 riots exemplify the local coercive capacity to change or appropriate the externally set benchmarks and policy agendas.

The 2006 internal security review conducted in parallel with the status talks is another example of legitimization and appropriation. It was initiated to revitalize the stagnated political environment in Kosovo and restore the strained relationships with the domestic elites whose cooperation and compliance were essential for the legitimacy and effectiveness of the internationally led institution-building process. It was, however, realized as a problemsolving exercise to 'cure' the territory's internal security 'pathologies' felt strongly during the 2004 riots (therapy). In terms of methodology, the review was premised on a holistic and inclusive perspective, evidenced by the collection of public inputs through surveys and the 'have your say' bus. However, Kosovars' preference for the creation of an army was disregarded and the formation of a lightly armed security force (KSF) was recommended in both the review and the Ahtisaari plan (consultation). While not fully satisfying the local demands, the review and its proposed actions were approved by the political leadership whose priority at the time was formally separating from Serbia and maintaining the much needed international sympathy for this objective.

With the recognition of independence, mutual dependencies took a new form. Kosovo's 'internationally supervised' independence meant continuing international engagement with the capacity-development of its institutions including the security and justice sectors, while the Kosovo authorities sought to redefine the parameters of power relationships with their foreign 
partners. The process of developing the country's national security strategy is a case in point to illustrate how these power-based interplays have developed. The strategic document was largely viewed as the imposition of outsiders' will due to ICO officials' interventions. In the face of strong pressure, the government had to approve the strategic document but resisted its implementation and initiated a new internal review process in 2012. Another example is the proposed transformation of the KSF into a national army that includes the devolution of responsibility for security from NATO. The government's efforts to create an army that will be in charge of security represent an aspiration to assert full sovereignty both internally and externally (delegated power). However, the planned transformation is a challenging task for the government as it requires changing the constitution which seems unlikely to occur given the clear Serb opposition. The local leadership is aware of the need for international backing for realizing its project. In an attempt to garner international support, which could be seen as another example of legitimization and appropriation of actions through 'ownership', the Kosovo authorities emphasize Kosovo's self-sufficiency through improving its own administrative and institutional structures including defence capabilities. ${ }^{124}$

\section{Acknowledgements}

This study is one of the products of the research project, entitled 'Policy and Practice of Integrated Security and Development as a Sustainable Peace-Building Strategy', supported by Turkey's Scientific and Technological Research Council (TUBITAK) under its Post-Doctoral Returns Programme.

\section{Disclosure statement}

No potential conflict of interest was reported by the author.

\section{About the author}

Selver B. Sahin is an assistant professor of international relations at Bilkent University, Ankara, Turkey. She is the author of International Intervention and StateMaking: How the Exception Became the Norm (Routledge, 2015). Her research is focused on the forms and consequences of state-capacity-building interventions and has been published in Democratization, Asian Survey, Australian Journal of International Affairs, and the Journal of Balkan and Near Eastern Studies.

\section{Bibliography}

Arnstein, Sherry. 'A Ladder of Citizen Participation.' Journal of the American Institute of Planners 35, no. 4 (1969): 216-24.

\footnotetext{
${ }^{124}$ See, for example, 'Ministry for the Kosovo Security Force Newsletter'.
} 
Bajraktari, Yll, and Christina Parajon. 'The Future of Kosovo's Security Sector.' USI Peace Briefing, 1 Dec. 2006.

Bendix, Daniel, and Ruth Stanley. 'Deconstructing Local Ownership of Security Sector Reform: A Review of the Literature.' African Security Review 17, no. 2 (2008): 93-104.

Blease, Dennis, and Florian Qehaja. 'The Conundrum of Local Ownership in Developing a Security Sector: The Case of Kosovo.' New Balkan Politics 14 (2013): 1-21.

Boege, Volker. 'Hybrid Forms of Peace and Order on a South Sea Island: Experiences from Bougainville (Papua New Guinea).' In Hybrid Forms of Peace: From Everyday Agency to Post-Liberalism, ed. Audra Mitchell and Oliver P. Richmond, 88-106. New York: Palgrave Macmillan, 2012.

Chandler, David. Empire in Denial: The Politics of State-Building. London: Pluto Press, 2006.

Chandler, David. International Statebuilding: The Rise of Post-Liberal Governance. London: Routledge, 2010.

Chesterman, Simon. 'Ownership in Theory and in Practice: Transfer of Authority in UN Statebuilding Operations.' Journal of Intervention and Statebuilding 1, no. 1 (2007): 3-26.

Cleland Welch, Anthony. 'Appraising the 2006 Kosovo Internal Security Sector Review - Part 1.' Centre for Security Governance, 10 Jun. 2014.

Cleland Welch, Anthony. 'Kosovo's Home-Grown SSR: The Strategic Security Sector Review.' Center for Security Governance, 19 Jun. 2014.

Cleland Welch, Anthony. 'A Security Sector Review in Kosovo: An Holistic Approach to SSR.' In Security Sector Reform in South East Europe - from a Necessary Remedy to a Global Concept, ed. Anja H. Ebnoether, Ernst M. Felberbauer and Mladen Stanicic, 43-56. Vienna: National Defence Academy and Bureau for Security Policy, 2007.

Cleland Welch, Anthony, Sokol Kondi, Dana Stinson and Michael von Tangen Page. Kosovo Internal Security Sector Review. Pristina: UNDP, 2006.

Derks-Normandin, Maria. Linking Peace and Durable Solutions in a Multi-Ethnic Society: The Case of Kosovo. Washington DC: Brookings Institute, 2014.

DFID (United Kingdom Department for International Development). Eliminating World Poverty: Building Our Common Future. London: DFID, 2009.

DFID. Understanding and Supporting Security Sector Reform. London: DFID, 2002.

Donais, Timothy. 'Inclusion or Exclusion? Local Ownership and Security Sector Reform.' Studies in Social Justice 3, no. 1 (2009): 117-31.

Donais, Timothy. 'Understanding Local Ownership in Security Sector Reform.' In Local Ownership and Security Sector Reform, ed. Timothy Donais, 3-18. Geneva: LIT Verlag, 2008.

'Draft Law on the Armed Forces to Be Proceeded after the Draft Law on the Special Court.' Gazeta Express, 11 Jun. 2015.

Eide, Kai. 'A Comprehensive Review of the Situation in Kosovo.' Annex to UN doc. S/ 2005/635, 7 Oct. 2005.

Eide, Kai. 'Report of the Situation in Kosovo.' Annex to UN doc. S/2004/932, 30 Nov. 2004.

Elias, Norbert. What Is Sociology? New York: Columbia University Press, 1978.

Ezik, Tolga. 'Under Western Pressure, Kosovo Votes in Favour of the Creation of the War Crimes Court.' AVIM, 12 Aug. 2015. 
Forum for Civic Initiatives (FIQ), GAP Institute, the Institute for Development Policy (INDEP) and Kosovo Law Institute (KLI). 'The New Kosovo Security Strategy Formulation Process: Inclusiveness and Transparency.' 2013.

Gippert, Birte Julia. 'Exploring Local Compliance with Peacebuilding Reforms: Legitimacy, Coercion and Reward-Seeking in Police Reform in Kosovo.' International Peacekeeping 23, no. 1 (2016): 52-78.

Gordon, Eleanor. 'Security Sector Reform, Statebuilding and Local Ownership: Securing the State or Its People?' Journal of Intervention and Statebuilding 8, no. 2 (2014): 126-48.

Government of Republic of Kosovo. Analysis of the Strategic Security Sector Review of the Republic of Kosovo. Pristina, Mar. 2014.

Hajdari, Una. 'Kosovo Serbs MPs Say “No” to Kosovo Army.' Balkan Insight, 29 May 2015.

Heinemann-Gruder, Andreas, and Wolf-Christian Paes. 'Wag the Dog: The Mobilization and Demobilisation of the Kosovo Liberation Army.' Bonn International Centre for Conversion. Brief 20, 2001.

International Crisis Group (ICG). 'Collapse in Kosovo.' ICG Europe Report no. 155, 22 Apr. 2004.

International Crisis Group (ICG). 'Timor-Leste: Time for the UN to Step Back.' Asia Briefing no. 116. Dili, Brussels: ICG, 15 Dec. 2010.

International Organization for Migration (IOM). 'Kosovo Reintegration Efforts Are Bearing Fruits.' IOM Release, 16 Mar. 2000.

Kosovar Centre for Security Studies. Kosovo Security Barometer Fourth Edition. Pristina, Dec. 2014.

Kosovar Centre for Security Studies. Kosovo Security Barometer. Dec. 2015.

Kosovar Institute for Policy Research and Development (KIPRED). The Kosovo Security Sector Observer 1, no. 1. Pristina Jul. 2015.

'Kosovo to Create Own Army to "Protect Sovereignty".' Agence France-Presse, 6 Mar. 2014.

'Kosovo MPs to Vote Creating Army Soon.' Balkan Insight, 8 Jul. 2015.

'Law No. 04/L-177 on Overseas Deployment of the Kosovo Security Force.' Official Gazette of Republic of Kosovo, 28 May 2013.

Mac Ginty, Roger. 'Where Is the Local? Critical Localism and Peacebuilding.' Third World Quarterly 36, no. 5 (2015): 840-56.

Martin, Alex, and Peter Wilson. 'Security Sector Evolution: Which Locals? Ownership of What?' In Local Ownership and Security Sector Reform, ed. Tim Donais, 83-103. Geneva: DCAF, 2008.

Ministry of Kosovo Security Force. Annual Report 2014. Pristina, Dec. 2014.

'Ministry for the Kosovo Security Force Newsletter', Nov. 2015.

Mobekk, Eirin. 'Security Sector Reform and the Challenges of Ownership.' In The Future of Security Sector Reform, ed. Mark Sedra, 230-43. Ontario: Centre for International Governance Innovation (CIGI).

Nathan, Laurie. 'The Challenge of Local Ownership of SSR: From Donor Rhetoric to Practice.' In Local Ownership and Security Sector Reform, ed. Timothy Donais, 1936. Geneva: DCAF, 2008.

Nathan, Laurie. No Ownership, No Commitment: A Guide to Local Ownership of Security Sector Reform. Birmingham: University of Birmingham, 2007.

NATO. 'Joint Press Point with NATO Secretary General Jens Stoltenberg and Isa Mustafa of Kosovo.' 23 Jan. 2015. 
OECD/DAC (Organization for Economic Cooperation and Development/ Development Assistance Committee). Do No Harm: International Support for Statebuilding. Paris: OECD, 2010.

OECD/DAC. Monitoring the Principles for Good International Engagement in Fragile States and Situations - Fragile States Principles Monitoring Survey: Global Report. Paris: OECD, 2010.

OECD/DAC. OECD-DAC Handbook on Security System Reform (SSR): Supporting Security and Justice. Paris: OECD, 2007.

OECD/DAC. 'Principles for Good International Engagement in Fragile States and Situations.' Apr. 2007.

OECD/DAC. Security System Reform and Governance. Paris: OECD, 2005.

OECD/DAC. Security System Reform: What Have We Learned? Paris: OECD, 2008.

OECD/DAC. Supporting Statebuilding in Situations of Conflict and Fragility: Policy Guidance. Guidelines and Reference Series. Paris: OECD, 2011.

O’Neill, William G. Kosovo: An Unfinished Peace. Boulder, CO: Lynne Rienner, 2002. Pinto, Julio Tomas. 'UNMIT Mission: Development or Destruction.' Tempo Semanal, 7 Jun. 2011.

Rayroux, Antoine, and Nina Wilen. 'Resisting Ownership: The Paralysis of EU Peacebuilding in the Congo.' African Security 7, no. 1 (2014): 24-44.

Rees, Edward. Security Sector Reform (SSR) and Peace Operations: 'Improvisation and Confusion' from the Field. New York: United Nations Department of Peacekeeping Operations, 2006.

Richmond, Oliver P. 'De-Romanticising the Local, Demystifying the International: Hybridity in Timor Leste and the Solomon Islands.' Pacific Review 24, no. 1 (2011): 115-36.

Richmond, Oliver P. A Post-Liberal Peace. London and New York: Routledge, 2011.

Richmond, Oliver P. 'Resistance and the Post-Liberal Peace.' Millennium: Journal of International Studies 38, no. 3 (2010): 665-92.

Saferworld. 'The Internal Security Sector Review: The Future of Kosovo's Security Sector?' 31 Jan. 2007.

Sahin, Selver B., and Donald Feaver. 'The Politics of Security Sector Reform in "Fragile" or "Post-Conflict" Settings: A Critical Review of the Experience in Timor-Leste.' Democratization 20, no. 6 (2012): 1-25.

Scheye, Eric. 'Unknotting Local Ownership Redux: Bringing Non-State/Local Justice Networks Back in.' In Local Ownership and Security Sector Reform, ed. Timothy Donais, 59-81. Geneva: DCAF, 2008.

Scheye, Eric, and Gordon Peake. 'Unknotting Local Ownership.' In After Intervention: Public Security in Post-Conflict Societies: From Intervention to Sustainable Local Ownership, ed. Anja Ebnother and Philipp Fluri, 235-60. Vienna and Geneva: Geneva Centre for the Democratic Control of Armed Forces (DCAF), 2005.

'Standards for Kosovo.' 10 Dec. 2003. http://www.securitycouncilreport.org/atf/ cf/\%7B65BFCF9B-6D27-4E9C-8CD3-CF6E4FF96FF9\%7D/Kos\%20Standards.pdf (accessed 12 Nov. 2014).

'Thaci: Pristina Has NATO’s Approval to Establish Army.' b92, 29 Sep. 2015.

'The Establishment of Kosovo with Many Unkowns.' Independent Balkans News Agency, 27 Feb. 2015.

UN. 'An Agenda for Peace.' A/47/277, 17 Jun. 1992.

UN. A More Secure World: Our Shared Responsibility. Report of the High-Level Panel on Threats, Challenges and Change. New York: UN, 2004. 
UN. 'Report of the Secretary-General on the United Nations Interim Administration Mission in Kosovo.' S/2004/348, 30 Apr. 2004.

UN. 'Report of the Secretary-General on the United Nations Interim Mission in Kosovo.' S/2000/177, 3 Mar. 2000.

UN. 'Report of the Special Envoy of the Secretary-General on Kosovo's Future Status.' S/2007/168, 26 Mar. 2007.

UN. 'Securing Peace and Development: The Role of the United Nations in Supporting Security Sector Reform.' A/62/659-S/2008/39, 23 Jan. 2008.

UN. 'Securing States and Societies: Strengthening the United Nations Comprehensive Support to Security Sector Reform.' A/67/970-S/2013/48013, 13 Aug. 2013.

UN. 'UN Interim Administration Mission in Kosovo (UNMIK): 09 Feb 2000.' UNMIK Press Release, 9 Feb. 2000.

UNDP. Peace for Governance: Securing the Social Contract. New York: UN Publications, 2012.

UNMIK. 'Kosovo Protection Corps.' UNMIK Press Release, 13 Dec. 2002. http:// archive.is/jZc0F (accessed 22 Jul. 2015).

UNMIK. 'UNMIK Convenes First Meeting of Kosovo Transitional Council.' UNMIK Press Release, 16 Jul. 1999.

UNMIK. 'UNMIK Regulation No. 8.' On the Establishment of the Kosovo Protection Corps. UNMIK/REG/1999/8, 20 Sep. 1999.

UNMIK. 'UNMIK Regulation No. 1999/24.' On the Law Applicable in Kosovo. UNMIK/REG/1999/24, 12 Dec. 1999.

Von Billerbeck, Sarah B.K. 'Local Ownership and UN Peacebuilding: Discourse versus Operationalization.' Global Governance 21 (2015): 299-315.

Whalan, Jeni. How Peace Operations Work: Power, Legitimacy, and Effectiveness. Oxford: Oxford University Press, 2013.

Wilen, Nina. 'A Hybrid Peace through Locally Owned and Externally Financed SSRDDR in Rwanda?' Third World Quarterly 33, no. 7 (2012): 1323-36.

Wilson, Bu. 'Smoke and Mirrors: The Development of the East Timorese Police 19992009.' PhD diss., Australian National University, Canberra, Australia, 2010.

World Bank. 2011 World Development Report: Conflict, Security and Development. Washington, DC: World Bank, 2011.

Yannis, Alexandros. 'Kosovo under International Administration.' Survival 43, no. 2 (2001): 31-48. 